\title{
KARAKTERISTIK PENDERITA TUBERKULOSIS ANAK DI PUSKESMAS SAIL PEKANBARU
}

\author{
Novelis Lulu Fiorentiani, Tri Siwi KN, \\ Prodi Keperawatan, FMIPA \& Kesehatan, Universitas Muhammadiyah Riau, \\ Jl. Tuanku Tambusai No 02 Pekanbaru \\ Email : trisiwi@umri.ac.id
}

\begin{abstract}
ABSTRAK
Tuberkulosis (TB) adalah penyakit infeksi menular yang disebabkan oleh kuman TB (Mycobacterium Tuberculosis). TB pada anak sering terjadi tanpa gejala yang spesifik. Faktor risiko yang berperan penting dalam penularan penyakit TB pada anak adalah adanya riwayat kontak anak dengan penderita TB dewasa, status gizi anak, dan status imunisasi BCG. Tujuan penelitian ini adalah untuk melihat karakteristik Penderita Tuberkulosis Anak Di Puskesmas Sail Pekanbaru. Jenis penelitian yang digunakan adalah metode deskriptif dengan teknik pengambilan sampel total sampling dengan jumlah 12 orang anak. Metode pengumpulan data menggunakan data sekunder dari catatan rekam medik pasien dan data hasil wawancara dengan penanggungjawab TB dengan menggunakan lembar check list dengan analisa data univariate. Hasil penelitian menunjukkan bahwa anak yang menderita TB memiliki karakteristik mayoritas berusia 212 tahun .Jenis kelamin penderita TB anak antara laki-laki dan perempuan berbanding sama dengan jumlah 6 orang $(50 \%)$. Mayoritas anak dinyatakan positif mengalami TB berdasarkan pemeriksaan tes mantoux sebanyak 11 orang $(91.7 \%)$. Anak yang positif menderita TB yang terdapat riwayat kontak dengan penderita TB hanya 4 orang (58.3\%). Semua anak yang menderita TB memiliki riwayat pernah diberi imunisasi BCG . Berdasarkan status sosial ekonomi anak yang menderita TB berasal dari status ekonomi tinggi dan menengah berbanding sama yang masing masing berjumlah 6 orang (50\%). Ventilasi rumah penderita TB yang kurang baik sebanyak 7 orang (58.3\%). Pencahayaan rumah penderita TB mayoritas tidak terang sebanyak 8 responden (66.7\%). Disarankan kepada petugas kesehatan Puskesmas Sail untuk lebih meningkatkan kegiatan edukasi kesehatan kepada masyarakat tentang karakteristik tuberkulosis untuk meningkatkan pengetahuan masyarakat serta meningkatkan kesadaran masyarakat untuk memiliki prilaku hidup bersih dan sehat yang lebih baik untuk mengurangi terjadinya penyakit tuberculosis.
\end{abstract}

Kata Kunci

\section{: Karakteristik, Tuberkulosis anak}

\section{ABSTRACT}

Tuberculosis (TB) is a contagious infectious disease caused by Mycobacterium Tuberculosis bacteria. TB in children often occurs without specific symptoms. Risk factors that play an important role in the transmission of TB disease in children are the history of contact between children and adult TB sufferers, nutritional status of children, and BCG immunization status. The purpose of this study was to see the characteristics of Pediatric Tuberculosis Patients at the Sail Pekanbaru Health Center. The type of research used is descriptive method with total sampling technique with a total of 12 children. Data collection methods used secondary data from patient medical records and data from interviews with TB responsible people using a check list sheet with univariate data analysis. The results showed that the majority of children suffering from TB had the characteristics of aged 2-12 years. The sex of children with TB between boys and girls was the same as the number of 6 people (50\%). The majority of children tested positive for TB based on the Mantoux test as many as 11 people $(91.7 \%)$. Only 4 children who were positive for TB with a history of contact with TB patients (58.3\%). All children with TB have a history of being given BCG immunization. Based on the socioeconomic status of children suffering from TB come from high and middle economic status compared to the same, each of which amounted to 6 people (50\%). The house ventilation of TB patients that is not good enough is 7 people (58.3\%). The majority of TB sufferers' house lighting was not bright as many as 8 respondents $(66.7 \%)$. It is suggested to the health workers at the Sail Health Center to further increase health education activities to the public about the characteristics of tuberculosis to increase public knowledge and increase public awareness to have better clean and healthy living habits to reduce the occurrence of tuberculosis.

Keywords: Characteristics, Child tuberculosis 


\section{PENDAHULUAN}

Tuberkulosis (TB) merupakan penyakit infeksi menular yang dapat menyerang paru paru maupun pada ekstra paru paru. Secara global, di dunia terdapat 10,4 juta jiwa kasus penderita TB pada tahun 2016 . Angka kejadian TB diperkirakan 120 kasus per 100.000 penduduk. Menurut laporan Word Health Organization (WHO) tahun 2009, Indonesia menduduki peringkat kedua setelah India (Kemenkes RI, 2018).

\section{Menurut WHO (Would} Health Organization tahun) dalam Global Tuberculosis Report pada tahun 2013 menyatakan bahwa dari 530.000 kasus TB di dunia terdapat 74.000 kasus TB anak. Berdasarkan hasil laporan perkembangan penyakit TB tahun 2012, jumlah proporsi TB pada anak di Indonesia 8,2\% (Puspitasari, Amanda Ratih dkk, 2015). Data riset kesehatan daerah tahun 2013 tercatat yang mengalami Tb umur $<1$ tahun sebanyak $2 \%$, umur 1-4 tahun sebanyak 4\% dan kelompok umur 5-14 tahun sebanyak $0,30 \%$. Sedangkan pada kelompok umur dewasa menunjukkan prevalensi yang sama yaitu sebesar $3 \%$ Hal ini menunjukkan bahwa telah terjadi masalah baru yang mana penyakit TB sudah menyerang pada kelompok nbalita dan anak anak. Meskipun kasus TB pada anak terjadi $11 \%$ dari kasus TB yang ada, sangat perlu diperhatikan karena dapat menyebabkan komplikasi dn berkembng menjadi TB milier, TB meningitis yang dapat mengkibatkn kecacatan dan kematian ( Morcillo, 2007 dalam Kusuma Surya Irma, 2011).
Banyak faktor yang berhubungan dengan kejadian penyakit tuberculosis pada anak. Faktor yang memungkinkan terjadinya penyakit TB pada anak adalah faktor kepadatan penduduk ,status imunisasi BCG, status social ekonomi dan Riwayat kontak dengan penderita TB. Faktor agen dan lingkungan adalah faktor yang berperan dalam kejadian penyakit tuberculosis atau karakteristik yang ada pada anak dengan TB. (Yani Indra Desi, dkk, 2018, Febrian AM,2015).

Karakteristik merupakan ciri khas seseorang yang mempengaruhi pola kehidupan yang berbeda satu dengan yang lainnya yang terdiri dari ciri demografi, struktur social, dan manfaat pelayanan kesehatan ( Notoadmodjo, 2012).

\section{METODE PENELITIAN}

Metode penelitian ini menggunakan desain deskriptif dengan pengambilan sampel data sekunder berupa data catatan rekam medik dan hasil wawancara dengan penanggung jawab TB menggunakan lembar checklist. Analisis data menggunakan distribusi frekuensi univariat menggunakan bantuan program SPSS.

\section{HASIL DAN PEMBAHASAN}

Hasil penelitian yang telah dilaksanakan di Puskesmas Sail Pekanbaru adalah sebagai berikut : 
Tabel 1.1

Distribusi Frekuensi Usia

Penderita Tuberkulosis Anak

Di Puskesmas Sail Pekanbaru

Juli 2020

\begin{tabular}{l|l|l|l|l}
\hline Variabel & Mean & $\begin{array}{l}\text { Standar } \\
\text { Deviation }\end{array}$ & $\begin{array}{l}\text { Min- } \\
\text { Max }\end{array}$ & $\begin{array}{l}\text { Confidence } \\
\text { Interval } \\
95 \%\end{array}$ \\
\hline Usia & 6.67 & 2.741 & $2-12$ & $4.92-8.41$ \\
\hline
\end{tabular}

Berdasarkan tabel 1.1 diketahui bahwa usia penderita tuberkulosis paling rendah berumur 2 tahun dan tertinggi berusia 12 tahun. Rata-rata usia penderita tuberkulosis ini adalah antara usia (4.92-8.41\%)

Tabel 1.2

Distribusi Frekuensi Jenis

Kelamin Penderita

Tuberkulosis Anak

Di Puskesmas Sail Pekanbaru

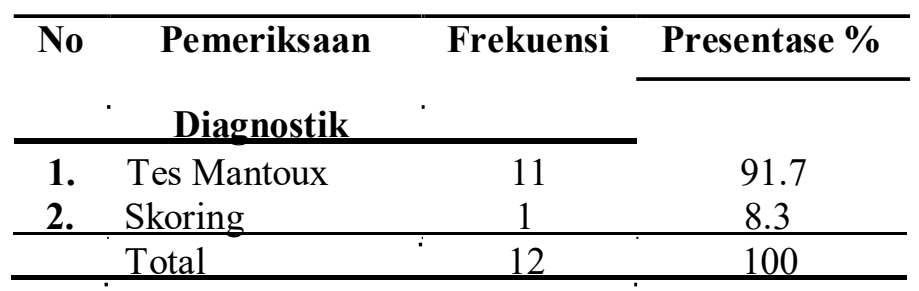

Berdasarkan tabel 1.3 diatas dapat dilihat bahwa mayoritas responden dinyatakan positif mengalami tuberkuloisis melalui pemeriksaan diagnostik tes mantoux sebanyak 11 orang $(91.7 \%)$.

Tabel 1.4

Distribusi Frekuensi

berdasarkan Riwayat Kontak

Dengan Penderita

Tuberkulosis Di Puskesmas

Sail Pekanbaru

\section{\begin{tabular}{llll}
\hline No & Jenis & Frekuensi & Presentase
\end{tabular}}

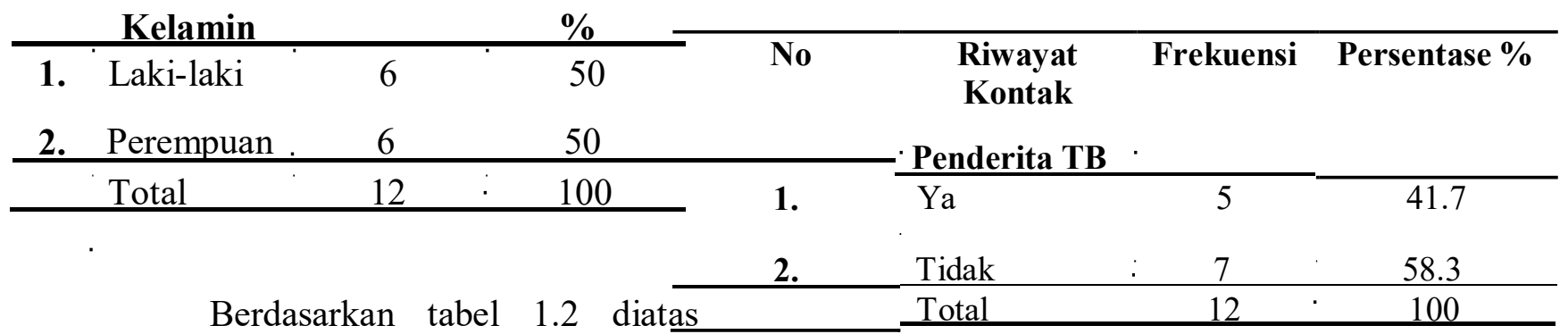

menunjukkan dapat dilihat bahwa jenis kelamin penderita tuberkulosis antara laki-laki dan perempuan berbanding sama dengan jumlah masing-masing 6 orang $(50.0 \%)$.
Berdasarkan tabel 1.4 diatas menunjukkan bahwa yang terbanyak pasien tuberculosis tidak ada riwayat kontak dengan penderita tuberculosis sebanyak 7 orang (58.3\%). 
Tabel 1.5

Distribusi Frekuensi

karakteristik berdasarkan

Riwayat Imunisasi Responden

Di Puskesmas Sail Pekanbaru
Tabel 1.7

Distribusi Frekuensi

Berdasarkan Ventilasi Rumah

Penderita Tuberkulosis Anak

Di Puskesmas Sail Pekanbaru

\begin{tabular}{|c|c|c|c|c|c|c|c|}
\hline No & $\begin{array}{l}\text { Riwayat } \\
\text { Hmmisas }\end{array}$ & Frekuensi & $\begin{array}{c}\text { Persentase } \\
\% \\
\%\end{array}$ & No & $\begin{array}{l}\text { Ventilasi } \\
\text { Rumah }\end{array}$ & Frekuensi & $\begin{array}{c}\text { Persentase } \\
\% \\
\end{array}$ \\
\hline 1. & Ya & 12 & 100.0 & 1. & Baik & 5 & 41.7 \\
\hline 2. & Tidak & 0 & 0 & 2. & Kurang & 7 & 58.3 \\
\hline & Total & 12 & 100 & & baik & 12 & 100 \\
\hline
\end{tabular}

Berdasarkan tabel 1.5 diatas dapat dilihat bahwa semua responden memiliki riwayat telah imunisasi sebanyak 12 orang anak $(100,0 \%)$.

Tabel 1.6

Distribusi Frekuensi

Berdasarkan Status Sosial Ekonomi

Keluarga Penderita Tuberkulosis Di

Puskesmas Sail Pekanbaru

\begin{tabular}{llcc}
\hline No & $\begin{array}{l}\text { Status } \\
\text { Soaial }\end{array}$ & $\begin{array}{c}\text { Frekue } \\
\text { nsi }\end{array}$ & $\begin{array}{c}\text { Persentase } \\
\text { \% }\end{array}$ \\
\cline { 1 - 2 } & Ekonomi & & \\
1. & $\begin{array}{l}\text { Tinggi }(\geq \\
5.000 .000)\end{array}$ & 6 & 50.0 \\
2. & $\begin{array}{l}\text { Sedang } \\
(2.880 .000-\end{array}$ & 6 & 50.0 \\
& $\begin{array}{l}4.990 .000) \\
\text { 3. }\end{array}$ & & \\
\hline & $\begin{array}{l}\text { Rendah }(< \\
2.880 .000)\end{array}$ & 0 & 0 \\
\hline & Total & 12 & 100 \\
\hline
\end{tabular}

Berdasarkan tabel 1.6 diatas menunjukkan bahwa responden yang mengalami tuberculosis berasal dari status sosial ekonomi tinggi dan sedang dengan jumlah berbanding sama masing- masing sebanyak 6 orang anak $(50,0 \%)$.
Berdasarkan tabel 1.7 diatas dapat dilihat bahwa responden yang mengalami tuberculosis berasal dari keluarga yang tidak memiliki ventilasi yang cukup sebanyak 7 orang $(58,3 \%)$, dan yang brasal dari keluarga yang memiliki ventlasi sebanyak 5 orang $(41.7 \%)$.

Tabel 1.8

Distribusi Frekuensi Berdasarkan Pencahayaan Rumah Penderita

Tuberkulosis Anak Di

Puskesmas Sail Pekanbaru

\begin{tabular}{|c|c|c|c|}
\hline No & Pencahayaan & Frek & Persentase \\
\hline & Rumah & uensi & $\%$ \\
\hline 1. & Terang & 4 & 33.3 \\
\hline 2. & Tidak Terang & 8 & 66.7 \\
\hline & Total & 12 & 100 \\
\hline
\end{tabular}

Berdasarkan tabel 1.8 diatas terlihat bahwa penderita tuberkulosis paling banyak berasal dari keluarga yang pencahayaan rumahnya tidak terang sebanyak 8 orang $(66.7 \%)$.Usia anak yang menderita tuberkulosis di Puskesmas Sail Pekanbaru antara umur (2-12) tahun (4.92-8.41\%). Hal ini sesuai dengan Guidance For National Tuberkulosis 
Programmes on the Management of Tuberkulosis in Children oleh WHO yang menyatakan bahwa risiko berkembangnya penyakit paling tinggi pada anak di bawah usia 5 tahun. Hal ini juga sejalan dengan hasil penelitian Varaine et al, (2010) yang menyebutkan bahwa anak usia 5 tahun kebawah beresiko 2 kali menderita TB aktif . Hasil penelitian Kusuma Surya Irma memperoleh hasil responden yang menderita $\mathrm{TB}$, rata rata anak berusia 6 bulan smpai 12 tahun (Kusuma Surya Irma, 2011)

Berdasarkan hasil penelitian, karakteristik responden berdasarkan riwayat kontak dengan penderita tuberkulosis, menunjukkan bahwa sebanyak 7 penderita tuberkulosis tidak mempunyai riwayat kontak dengan penderita tuberculosis $(58.3 \%)$, dan 5 orang penderita tuberkulosis yang terkontak dengan penderita tuberculosis (41.7\%).

Hal di atas sesuai dengan hasil penelitian Puspitasari Amanda Ratih, dkk (2015) bahwa hasil penelitiannya adalah tidak ada keterkaitan kontak penderita tuberculosis anak dengan orang lain yang terkena tuberculosis dengan kejadian tuberkulosis anak. $64.5 \%$ penderita $\mathrm{Tb}$ tidak mengalami kontak dengan pasien tuberkulosis positif. Padahal kuman tuberkulosis dapat menyebar hanya dengan melalui percikan dahak (droplet) yang dihasilan seseorang penderita pada saat batuk, bersin, atau sedang berbicara. Hasil penelitian Dudeng dkk menyatakan bahwa anak yang pernah kontak dengan orang dewasa yang menderita TB dengan BTA positif, akan memiliki resiko 3,91 kali dibandingkan dengan yang tidak ppernah ada kontak dengan penderita
TB. Semakin sering dan lama kontak dengan penderita $\mathrm{TB}$, semakin besar terjadi resiko penularan. Sumber penularan bagi bayi dan anak yang disebut sebagai kontak erat adalah orangtua, orang yang tinggal serumah dan orang yang sering berkunjung ke rumah ( Yulistyaningrum \& Rejeki Sri Sarwani Dwi (2010).

Pembahasan ketiga karakteristik responden berdasarkan riwayat imunisasi $\mathrm{BCG}$, menunjukkan bahwa semua responden memiliki riwayat pernah mendapatkan imunisasi BCG. Hal ini tidak sesuai dengan hasil penelitian Pamungkas Putri, dkk (2018) yang menunjukkan bahwa terdapat hubungan yang signifikan antara riwayat pemberian imunisasi BCG dengan kejadian tuberkulosis paru di Kabupaten Surakarta. Imunisasi BCG dapat mengurangi risiko anak terkena penyakit tuberkulosis paru dengan efektifitas sebesar 50\%. Imunitas yang terbentuk ketika bayi diberikan imunisasi BCG sebenarnya tidaklah menjamin sepenuhnya bayi akan terlindungi dari infeksi TB tetapi jika bayi tidak diberikan perlindungan dalam bentuk pemberian imunisasi BCG maka tidak memiliki sebuah perlindungan didalam tubuhnya dan jia terkena penyakit TB akan memiliki risiko mendapat komplikasi peyakit lainnya.

Keefektifan imunisasi BCG sangat bervariasi karena terdapat beberapa faktor yang dapat mempengaruhi efektifitas imunisasi BCG terhadap penyakit TB seperti perbedaan vaksin BCG yang diberikan, keterpaparan bakteri Mycobacterium Tuberculosis yang tinggi didalam lingkungan anak sehari hari, fator genetik yang 
dimiliki anak, status gizi anak dan faktor lainnya seperti adanya paparan sinar ultraviolet terhadap vaksin sehingga kualitas vaksin menjadi kurang baik serta kesalahan petugas kesehatan dalam melakukan penyuntikan sehingga kinerja vaksin yang diberikan menjadi tidak optimal (Michelsen WS et al, 2014)

\section{Karakteristik responden berdasarkan ventilasi rumah menunjukkan bahwa sebagian besar responden yang mengalami penyakit tuberculosis berasal dari keluarga yang memiliki ventilasi rumah yang kurang baik.. sebagian rumah yang mempunyai cukup ventilasi tapi rata- rata jarang untuk membukanya dikarenakan dirumah sudah memakai pendingin ruangan. Hal ini yang kemungkinan dapat menyebabkan responden mengalami penyakit tuberculosis. Rumah penderita TB yang memiliki ventilasi cukup, namun jarang dibuka adalah pasien yang berasal dari keluarga dengan status ekonomi tinggi.}

Status sosial ekonomi adalah sutu kedaan yng menggambrkan kemampuan finansial dan kemampuan materiil ( Baswori dan Juariyah, 2010 dalam Indrawati Sri Endang, 2015). Pada keluarga dengan status ekonomi tinggi mampu menyediakan semua kebutuhan anak baik primer maupun sekunder (Soetjiningsih, 2010). Namun demikian, status ekonomi yang tinggi kurang mendukung status kesehatan seseorang apabila tidak didukung dengan pengetahuan yang cukup.

Ventilasi merupakan komponen terpenting yang ada di dalam rumah karena ventilasi berfungsi sebagai pertukaran udara dari dalam keluar ruangan. Ventilasi yang kurang dapat mempengaruhi kualitas udara di dalam rumah. Ventilasi yang kurang dapat menyebabkan udara yang mengandung banyak kuman tuberkulosis akan mudah terhirup secara langsung oleh anak sehingga anak rentan mengalami penyakit TB. Ventilasi dapat mengurangi jumlah kuman TB dalam ruangan yang terbawa oleh aliran udara, sehingga dapat memperkecil kemungkinan penularan TB Paru pada penghuni rumah tersebut. Hasil penelitian Hapsari menunjukkan aadanya hubungan yang signifikan antara ventilasi dengaan kejadian TB (Hapsari Anggia Dewi, dkk, 2020).

Karakteristik pencahayaan rumah anak yang menderita $\mathrm{Tb}$ banyak yang pencahayaan rumahnya tidak terang sebanyak 8 orang anak (66.7\%). Pencahayaan secara alami dari sinar matahari langsung ke dalam rumah dapat membantu membunuh bakteri TB. Hal ini dikarenakan sinar matahari mengandung sinar ultraviolet dari maatahari pagi yang bisa membunuh kuman (Halim dkk, 2015 dalam Apriliaasari Rusliana dkk, 2018). Selain itu, pencahayaan erat kaitannya dengan tingkat kelembaban. Pencahayaan yang kurang akan menyebaban kelembaban yang tinggi di dalam rumah dan berpotensi sebagai tempat berkembang biaknya kuman TB (Putra, 2011).

Pencahayaan yang kurang terang dapat meningkatkan perkembangan kuman TB Paru karena cahaya matahari merupakan salah satu media yang dapat membunuh kuman TB, 
sehingga jika pencahayaan bagus dapat meminimalisir penularan dan perkembangbiakan kuman TB . Oleh karena itu rumah yang sehat sebaiknya memiliki pencahayaan alami sinar matahari yang mengandung sinar ultraviolet yang dapat menurunkan kadar jasad renik ( Siregar Apriadi Putra,dkk. 2011).

Hal ini tidak sejalan dengan penelitian Mawardi, Indah Farika Meyla, (2014), yang menyatakan bahwa tidak terdapat hubungan antara pencahayaan dengan kejadian TB dan hasil penelitian Susanti Ika Lusy (2016), bahwa sebagian besar rumah responden yang menderita tuberculosis pencahayaannya tidak memenuhi syarat yaitu sebanyak $71.43 \%$.

Kondisi pencahayaan merupakan salah satu faktor yang berhubungan dengan kejadian penyakit tuberculosis. Hal ini sesuai dengan hasil penelitian Khairunnisa (2017), yang menyatakan bahwa dengan pencahayaan yang kurang maka perkembangan kuman TB akan meningkat karena cahaya matahari merupakan salah satu faktor yang dapat membunuh kuman TB sehingga jika pencahayaan ruangan memenuhi syarat dapat mencegah penularan dan berkembangnya kuman TB .

Dengan demikian peneliti berpendapat bahwa faktor lain bisa terjadi yang dapat mempengaruhi terjadinya penyakit tuberculosis pada anak. Secara teori, biasanya karakteristik penderita tuberkulosis biasanya berasal dari anak yang tidak pernah diberikan imunisasi BCG, anak dari keluarga dengan status sosial menengah ke bawah, terdapat riwayat kontak dengan penderita tuberkulosis yang kemungkinan bisa tinggal satu rumah dengan penderita. Lingkungan berupa ventilasi yang kurang maupun pencahayaan yang kurang yang dapat memicu terjadinya kuman tubrkulosis brkembang di dalam rumah. Namun yang terjadi pada hasil penelitian, data penelitian yang diperoleh responden yang menderita tuberculosis di Puskesmas Sail memiliki riwayat pernah diimunisasi BCG, tidak pernah ada riwayat kontak dengan penderita TB , dan juga berasal dari keluarga yang menengah ke atas dan karakteristik yang sesuai dengan konsep karakteristik tuberculosis adalah jumlah ventlasi yang kurang maupun jumlah pencahayaan yang kurang. Hal ini perlu mendapatkan perhatian yang lebih dari puskesmas untuk lebih meningkatkan kegiatan Pendidikan kesehatan kepada masyarakat tentang faktor penyebab terjadinya penyakit tuberculosis.

\section{KESIMPULAN}

Berdasarkan hasil penelitian yang dilakukan di Puskesmas Sail Pekanbaru pada tanggal 28 - 31 Juli 2020 yang berjudul "Karakteristik Penderita Tuberkulosis Anak Di Puskesmas Sail Pekanbaru" sebagian besar responden memiliki karakteristik usia responden ratarata 2-12 tahun, responden dinyatakan positif mengalami tuberkulosis berdasarkan pemeriksaan diagnostik dengan tes mantoux dan skrinning. teresponden lebih banyak tidak ada riwayat kontak dengan penderita tuberkulosis yang lain. Selain itu responden berasal dari keluarga dengan status sosial ekonomi tinggi dan sedang dengan jumlah berbanding sama dan 
mayoritas responden berasal dari keluarga yang tidak memiliki ventilasi serta pencahayaan yang kurang.

\section{UCAPAN TERIMAKASIH}

Terimakasih peneliti ucapkan kepada semua pihak terutama kepada kepada Pimpinan Puskesmas Sail Pekanbaru serta Penanggung Jawab TB Puskesmas Sail Pekanbaru yang telah memberikan kontribusi positif untuk proses pelaksanaan kegiatan penelitian yang telah memberi kesempatan kepada peneliti untuk melakukan pengambilan data penelitian

\section{DAFTAR PUSTAKA}

Kemenkes RI. (2018). Tuberkulosis. Pusat data dan informasi tuberculosis. Jakarta.

Puspitasari AR (2015). Faktor yang berhubungan dengan kejadian tuberculosis pada anak ( studi di Balai Kesehatan Paru Masyarakat Semarang).Jurnal Kesehatan Masyarakat(e-Jurnal)volume 3, Nomor 1, Januari 2015.

Kusuma Surya Irma ( 2011). Faktor faktor yang berhubungan dengan kejadian tuberculosis paru pada anak yang berobat di Puskesmas Wilayah Kecamatan Cimanggis Depok. Universitas Indonesia. Fakultas Kesehatan Masyarakat Program Studi Ilmu Kesehatan Masyarakat Departemen Epidemiologi. Depok. Skripsi tidak diterbitkan.

Febrian AM (2015). Faktor factor yang berhubungan dengan kejadian TB paru anak di Wilayah Puskesmas Garuda Kota Bandung. Jurnal Ilmu Keperawatan. Volume III. Nomer 2. 2015.

Notoatmodjo, Soekidjo. (2012). Promosi Kesehatan dan Perilaku Kesehatan. Jakarta: Rineka Cipta.

Pamungkas Putri, dkk (2018). Evaluation of Multidrugs Resistent Tuberculosis predictor Index In Surakarta, Central Java. Journal of epidemiologyand Publich Health volume 3. No 2. 2018

Michelsen WS, et al (2014). The effectiveness of BCG vaccination in preventing Mycobacterium tuberculosis infection and disease in Greenland. Thorax: first published 10.11.36/thoraxjnl2014-205688. 26 Juni 2014.

Indrawati Sri Endang (2015). Status social ekonomi dan intensitas komunikasi keluarga pada ibu rumah tangga di Panggung Kidul Semarang Utara. Jurnal Psikologi UNDIP. Volume 4 No 1 April 2015.

Hapsari Anggia Dewi, dkk (2020). GFaktor yang berhubungan dengan kejadian tuberculosis pada pasien yang berkunjung ke puskesmas Dinoyo Kota Malang. Preventian: Journal of public health Volume 5 No 1 . Juni 2020.

Siregar Apriadi Putra, dkk (2018). Analisis faktor yang berhubungan dengan kejadian tuberculosis paru anak di RSUD Sibuhuan. Jurnal berkala epidemiologi . Volume 6 No 3 . 2018.

Mawardi, Indah Farika Meyla (2014). Hubungan kondisi fisik rumah 
dan kepadatan hunian dengan kejadian TB paru di wilayah kerja Puskesmas Dadahup Kecamatan Dadahup Kabupaten Kapuas. Jurnal Annadaa. Volume 1 Nomer 1Juni 2014.

Ika Susanti Ika Lusy (2016) Hubungan antara kondisi fisik rumah dan perilaku dengan kejadian tuberculosis paru di wilayah kerja Puskesmas Sangkrah Kota Surakarta. Program Studi Kesehatan Masyarakat. Fakultas Ilmu Kesehatan. Universitas Muhammadiyah Surakarta. Publikasi Ilmiah tidak diterbitkan.

Khairunnisa (2017). Faktor factor yang mempengaruhi kejadian TB Paru di Rumah Sakit Balai Paru Kota Makassar.Program Studi Pendidikan Dokter Umum. Fakultas Kedokteran Universitas Hasanuddin Makassar. Skripsi. Tidak dipublikasikan.

Yulistyaningrum dan Rejeki Sri sarwani Dwi (2010). Hubungan Riwayat Kontak Penderita TB Paru Dengan Kejadian TB Paru Anak Di Balai Pengobatan Penyakit Paru (BP4) Purwokerto.. Jurnal Fakultas Kesehatan Masyarakat KESMAS Universitas Ahmad Dahlan . Volume 4 Nomer 12010. 